\title{
How do the wets burn? Fire behavior and intensity in wet grasslands in the Brazilian savanna
}

\author{
Isabel B. Schmidt ${ }^{1,3} \cdot$ Alessandra Fidelis $^{2} \cdot$ Heloísa S. Miranda ${ }^{3} \cdot$ Tamara Ticktin $^{1}$
}

Received: 23 May 2016/Accepted: 7 October 2016/Published online: 22 October 2016

(C) Botanical Society of Sao Paulo 2016

\begin{abstract}
Although wetlands are commonly managed with fire by local communities and managers in tropical savannas, little is known about fire behavior in these ecosystems. We measured fire intensity and temperature in 13 experimental early (June) and late (September) dry season fires in wet grasslands in the Brazilian savanna, the "Cerrado". We aimed to characterize "Cerrado" wet grasslands fire behavior and to understand how fire season (early vs. late dry season) and time since last fire affect fire behavior and intensity. We compared fire intensities in biennially burnt areas to areas unburned for 5 years. Experimental fires consumed $60-98 \%$ of the fuel and were of low intensity (240-1083 $\mathrm{kW} \mathrm{m}^{-1}$ ) compared to those in dry savanna grassland with similar fuel loads $\left(0.4-1.3 \mathrm{~kg} \mathrm{~m}^{-2}\right)$. Fires in areas with contrasting times since last fire ( 2 and 5 years) had similar intensities. Late dry season fires tended to be more intense than early dry season fires, but the difference was not significant. The low fire intensities are probably due to high soil water availability year around, a characteristic of wetlands. Maximum temperatures were low $\left(149-442{ }^{\circ} \mathrm{C}\right.$, mostly at $50 \mathrm{~cm}$ in height) compared to fires in dry savanna ecosystems. Our results can directly contribute to plan and
\end{abstract}

Isabel B. Schmidt

isabels@unb.br

1 Botany Department and Ecology, Evolution \& Conservation Biology Program (EECB), University of Hawai'i at Mānoa, Honolulu, HI, USA

2 Departamento de Botânica, Instituto de Biociências, UNESPUniversidade Estadual Paulista, Rio Claro, Brazil

3 Present Address: Departamento de Ecologia, Universidade de Brasília, Campus Universitário Darcy Ribeiro, Brasília, DF CEP 70.910-900, Brazil implementation of fire management programs in the "Cerrado", where it is mostly still not carried out.

Keywords "Campos úmidos" . "Cerrado" .

Eriocaulaceae · Fire management · Fire season · Fire temperatures $\cdot$ Protected areas

\section{Introduction}

Historically and at present, fire is a common tool applied in the management of several fire-prone ecosystems (Whelan 1995; Bond et al. 2005; Furley et al. 2008). People set fire to open new areas for agriculture to induce the resprouting and flowering of plant species harvested by humans and grazed by livestock, to aid in hunting, to help avoid poisonous animals, and to improve access to new areas (Mistry 1998; Yibarbuk et al. 2001; McGregor et al. 2010).

Although fire is present in the "Cerrado", the Brazilian savanna, for millennia (Simon et al. 2009), the conservation policy for natural areas, including all legally protected areas (PAs), is mostly to avoid natural and human-induced fires (Ramos Neto and Pivello 2000). For the past several decades, the most common management approach in Brazilian PAs has been to focus on preventing, fighting, and controlling any type of fire, including natural, caused by lighting, and the controlled fires historically carried out by traditional communities (Durigan and Ratter 2016). Even with this 'zero-fire policy,' wildfires have not been eliminated from nearly any "Cerrado" PA, which have been affected by large-scale wildfires, especially during late dry season (August-September), every 2-3 years (França 2010; Pivello 2011; Pereira Junior et al. 2014).

As for other tropical and sub-tropical savannas (Andersen et al. 1998; Savadogo et al. 2007; VanWilgen et al. 
2007), prescribed fires could be applied to manage "Cerrado" ecosystems to avoid uncontrolled fires, protect firesensitive vegetation, and maintain biodiversity. Recently, management agencies have started to consider the possibility of implementing Integrated Fire Management (Myers 2006; VanWilgen et al. 2007) in some "Cerrado" PAs (Lobo 2014). However, Integrated Fire Management (IFM) implementation requires information on fire intensity, fire behavior, as well as plant community and population responses to fire in all "Cerrado" physiognomies. The lack of this information is commonly indicated as one of the challenges for establishing fire management policies in "Cerrado" PAs, since fire intensity and fire behavior influence the effects of fire on plant individuals, populations, communities, and ecosystems (Govender et al. 2006). On the other hand, plant community structure and composition affect fuel (biomass) characteristics, production, and accumulation which influence fire behavior and intensity (Bond and Keeley 2005). Therefore, basic information on fire intensity, fire behavior, and biomass production can significantly contribute to fire management implementation (Govender et al. 2006).

Savannas are characterized by marked seasonal rainfall and a mosaic of soils with varying fertilities and drainages, which support a mosaic of physiognomies from inundated to dry forests, including wet and dry grasslands with a significant variation in tree density (Furley 2004). Fire behavior and fire intensity vary widely among savanna physiognomies. Open savanna physiognomies, with continuous grass layer, carry fast surface fires, which are usually more intense than fires in savanna physiognomies with higher tree density (Trollope and Trollope 2002; Miranda et al. 2009). Also, aboveground biomass production and accumulation is faster in mesic savannas compared to dry savannas (Bond and Keeley 2005). These features influence fire return intervals across different savannas in the world and also across the various savanna physiognomies (Bond and Keeley 2005; Miranda et al. 2009).

Within savannas, areas such as inundated forests, swamps, and wet grasslands are islands of water availability all year around (Cianciaruso and Batalha 2008). Specifically in the Brazilian savanna, wet grasslands are economically and culturally important for local communities and are commonly managed with fire for cattle raising, subsistence agriculture, harvest of plant parts, and to protect adjacent riparian areas (Barbosa and Schmitz 1998; Schmidt et al. 2007; Falleiro 2011). Despite the cultural and socio-economic importance of wetlands, most studies on fire behavior in savannas are concentrated in the dry physiognomies (Andersen et al. 1998; VanWilgen et al. 2007; Furley et al. 2008; Miranda et al. 2009). Studies in perennial savanna grasslands are rarer (Zimmermann et al.
2010), and to our knowledge, no study to date has characterized fire behavior in tropical or sub-tropical savanna wetlands.

The Jalapão region (Tocantins state, northwest Brazil) encompasses one of the largest continuous areas of conserved "Cerrado" with the largest continuous legally protected areas in the "Cerrado" biome: Serra Geral Ecological Station, 713,000 ha and Jalapão State Park, 158,000 ha, which are contiguous with the Parnaiba Springs National Park, 733,000 ha (Silva and Bates 2002). Since these areas have been officially protected only since 2001 , most of the area is still traditionally managed by local communities. In the wet grasslands, fires are regularly set to induce resprouting of native grasses for cattle grazing, as well as to stimulate flowering of Syngonanthus nitens (Bong.) Ruhland (Eriocaulaceae) (Schmidt et al. 2007). The local communities in Jalapão consider annual fires to be too frequent and are associated with decreases in vegetation cover and consequent soil erosion; a biennial fire regime is considered to be ideal for both cattle grazing and $S$. nitens flower stalk harvest. However, fires in areas unburned for five or more years are considered more intense and, therefore, detrimental to the wet grassland plant community, including S. nitens and forage grasses than more frequent fires. On the other hand, fire at any time during the dry season (May-September) is believed to induce $S$. nitens flowering the following year (Schmidt 2011).

In this study, we aimed to characterize "Cerrado" wet grasslands fire behavior, including fire intensity, maximum temperatures, and high-temperature residence time. Specifically, we address the following questions: (i) Are late dry season fires (September) more intense than early dry season fires in "Cerrado" wet grasslands? (ii) Do areas with longer fire return interval have significantly higher fuel loads and, therefore, more intense fires than areas burned more frequently?

Experimentally characterizing basic fire behavior and intensity characteristics under contrasting conditions (early vs. late fires) as well as different frequencies ( 2 vs. 5 years since last fire) can help on the dialog between PA managers and local communities. These data can also inform environmental planning and fire management in the "Cerrado" region, where fire management is still incipient.

\section{Methods}

The study was performed in wet grasslands inside the Jalapão State Park $\left(10^{\circ} 15^{\prime} \mathrm{S} ; 44^{\circ} 40^{\prime} \mathrm{W}\right)$. The wet grasslands in Jalapão occur on organosoils and are dominated by Poaceae and Xyridaceae species with virtually no shrubs or trees. The wet grasslands form belts around palm swamps 
("veredas"), which frequently are mono-dominated by Mauritia flexuosa L.f. (Arecaceae) (Ratter et al. 1997). Local annual precipitation is around $1700 \mathrm{~mm}$, with $90 \%$ of rainfall concentrated between October and April, and mean annual temperature is $27^{\circ} \mathrm{C}$ (ANA 2010). Water table is superficial in the wet grasslands, which can be flooded during the rainiest months (November-January) (personal observation).

We performed experimental fires in five wet grasslands (sites 1-5), ranging from 3 to $27 \mathrm{~km}$ apart, historically managed with biennial fire by three local communities in Jalapão for both cattle grazing and S. nitens harvesting. All study sites were chosen in collaboration with local harvesters, are considered good harvesting areas, and had been burned by local harvesters in 2005, the year before the experiments were established (Schmidt and Ticktin 2012). In each wet grassland, we had three experimental plots: one burned biennially in early dry season (June); another burned biennially in late dry season (September); and a control plot (last fire in 2005) (Fig. 1). In each wet grassland, the plots varied from $100 \mathrm{~m}^{2}\left(10 \times 10 \mathrm{~m}^{2}\right)$ to $625 \mathrm{~m}^{2}$ $\left(25 \times 25 \mathrm{~m}^{2}\right)$ depending on the length of the wet grassland. The size of the plots, as well as a distance of at least $5 \mathrm{~m}$ between experimental plots allowed experimental fires to spread naturally after being started, and the measurements of the air temperature during fires were made at least $5 \mathrm{~m}$ from the starting point of the experimental fire. Study areas were fenced in June 2006 to avoid cattle grazing.

Prescribed fires were carried out in June and September 2009 (biennial fires) and in September 2010 (5 years without fire). The biennial plots had been experimentally burned in 2007, whereas the plots burned in 2010 had been protected from fires since 2005. For each fire, we estimated fuel load, fuel consumption, the rate of spread, fire intensity, and air temperature. Immediately before each fire, we measured wind velocity, air temperature, and humidity. All prescribed fires were head fires performed by the Jalapão State Park fire brigade and set between 8:30 am and 2:00 pm.

We estimated fuel load by collecting all the aboveground fine biomass $(<0.6 \mathrm{~cm})$ from six quadrats $(0.25 \times 0.25 \mathrm{~m})$ immediately before each fire. Quadrats were randomly distributed in the plots, at least $3 \mathrm{~m}$ away from the border. The same procedure was carried out immediately after the fires to estimate fuel consumption. The collected biomass was oven-dried $\left(80{ }^{\circ} \mathrm{C}\right.$, for $\left.72 \mathrm{~h}\right)$. We estimated fire rate of spread by measuring the time taken by the fire line to pass through two poles, $5 \mathrm{~m}$ apart, in the center of each plot. We calculated fire intensity according to the equation $I=h . w . r$ (Byram 1959), where $I$ is the fire intensity $\left(\mathrm{kW} \mathrm{m}^{-1}\right) ; h$ is the heat yield of the fuel $\left(\mathrm{kJ} \mathrm{kg}^{-1}\right) ; w$ is the fuel consumed per unit area $\left(\mathrm{kg} \mathrm{m}^{-2}\right)$; and $r$ is the rate of fire spread $\left(\mathrm{m} \mathrm{s}^{-1}\right)$. We considered the heat yield of the fuel to be $15,500 \mathrm{~kJ} \mathrm{~kg}^{-1}$ (Griffin and Friedel 1984), as for other studies carried out in "Cerrado" (Miranda et al. 2009; Pivello et al. 2010). We calculated heat released multiplying $h$ (the heat yield of the fuel, in $\mathrm{kJ} \mathrm{kg}^{-1}$ ) by $w$ (fuel consumed per unit area, in $\mathrm{kg} \mathrm{m}^{-2}$ ) (Whelan 1995).

We measured air temperatures during experimental fires using four chromel-alumel thermocouples (32 SWG) with temperatures recorded at one-second intervals, using a Campbell 21X data logger. Thermocouples were located at $1 \mathrm{~cm}$, just above $S$. nitens rosettes, and $50 \mathrm{~cm}$ above the soil surface, ca. height of the herbaceous layer vegetation. As fires are regularly set in the wet grasslands to stimulate flowering of $S$. nitens in the following dry season, two thermocouples were placed inside randomly selected $S$. nitens rosettes, and the relative water content (water mass/ dry mass) was determined for 50 rosettes in the late dry season fires of 2009 and 2010. The rosettes diameter varied from 3 to $4 \mathrm{~cm}$, which represents the average size of adult individuals in the plots (Schmidt 2011). Temperatures above $60{ }^{\circ} \mathrm{C}$ are commonly considered lethal for plant tissues (Kayll 1968; Dayamba et al. 2010); therefore, we characterized the residence time of such high temperatures $\left(>60{ }^{\circ} \mathrm{C}\right.$ ) for all thermocouples used during our experimental fires.

In September 2009, the burning was uneven in the experimental plot in site 1 and the data were not considered in the analysis. Due to a wildfire in 2007, there was no control plot (protected from fire for 5 years) in site 5. Therefore, the site was not burned in September 2010.

We compared fuel load across sites and dates using oneway ANOVA. The effect of time of fire (fire after 2 vs. 5 years since last fire), early and late dry season fires, in fire intensities and biomass consumption for the experimental fires in 2009 was tested with a paired $t$ test. To better understand the influence of abiotic parameters (wind speed, air temperature, and humidity) as well as fuel load in fire intensity, we performed linear regressions between each of these parameters and fire intensity. All data analyses were performed using $\mathrm{R}$ Program (Development Core Team 2016).

\section{Results}

Fuel load varied between 0.4 and $1.3 \mathrm{~kg} \mathrm{~m}^{-2}$ (Table 1) and was similar across sites at each fire period (June 2009: $F_{1,28}=1.41, P=0.24$; September 2009: $F_{1,28}=0.002$, $P=0.97$; September 2010: $F_{1,22}=0.17, P=0.68$ ). Fuel load $( \pm \mathrm{SD})$ was also similar in the experimental areas with different times since fire: $0.84 \pm 0.16$ and $0.69 \pm 0.14 \mathrm{~kg} \mathrm{~m}^{-2}$ for September 2009 (burned biennially) and September 2010 (protected from fire for 5 years) $\left(F_{1,52}=2.0, P=0.16\right)$. Fuel consumption varied from 60 

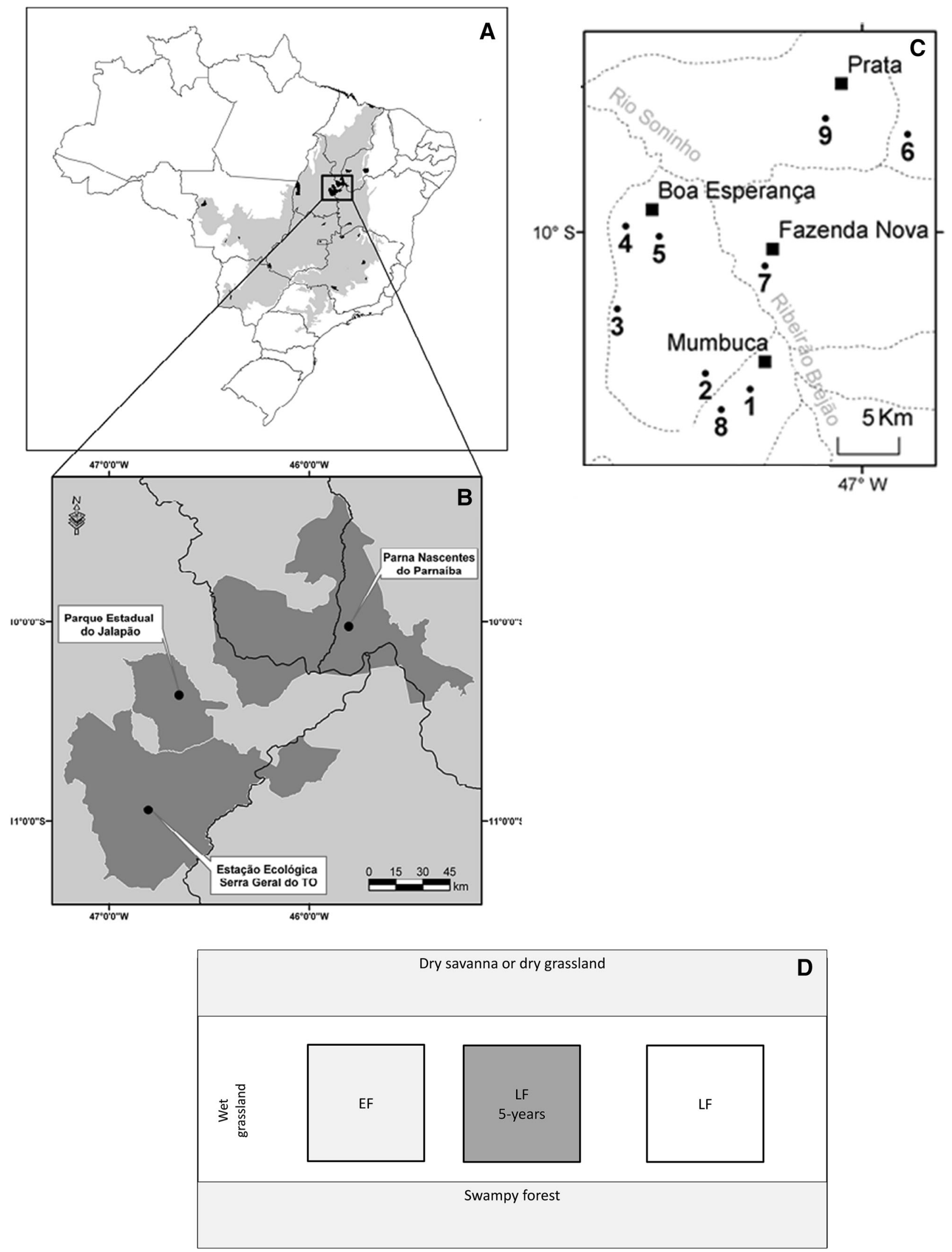
४Fig. 1 Brazilian territory with "Cerrado" biome delimited in grey with borders of the state of Tocantins in black and Jalapão region highlighted in the eastern Tocantins state (A); Jalapão region with the three main protected areas (B); distribution of four local communities (squares) within the Jalapão State Park who manage the five study sites of wet grasslands (circles) (C); schematic distribution of wet grasslands between swampy forests and dry grasslands of savanna vegetation (D), each of the five studied wet grasslands were divided into three plots which were experimentally burned biennially in early or late dry season (June and September 2009, EF and LF, respectively) or burned at late dry season 5 years since last fire

to $98 \%$ of the fuel load in the wet grasslands (Table 1) and was similar between early and late fires in 2009 ( $t=-1.4194$, df $=3, P=0.25$ ) and between late fires (September 2009 and 2010, paired $t$ test, $t=-0.6807$, df $=2, P=0.57$ ).

Fire intensity in wet grasslands in Jalapão ranged from 241 to $1090 \mathrm{~kW} \mathrm{~m}^{-1}$. Mean fire intensity $( \pm \mathrm{SD})$ was $470 \pm 236 \mathrm{~kW} \mathrm{~m}^{-1}$ for early fires, $750 \pm 147 \mathrm{~kW} \mathrm{~m}^{-1}$ in September 2009, and $761 \pm 231 \mathrm{~kW} \mathrm{~m}^{-1}$ in September 2010. The differences between early and late fires in the areas that were burned biennially (experimental fires in 2009) varied across sites and were not statistically significant $(t=-2.4$, df $=3, P=0.1)$. Fire intensity values were not significantly correlated to air temperature, air humidity, or fuel load $(P>0.6)$; however, increases in wind speed values at the time of the experimental fires significantly increased fire intensity $(P<0.05)$.

In 2009, the maximum temperatures during the experimental fires were recorded mostly at $50 \mathrm{~cm}$ height and varied from 150 to $442{ }^{\circ} \mathrm{C}$ (Table 2). The temperatures at $1 \mathrm{~cm}$ above the soil surface, just above the $S$. nitens rosettes, varied from 57 to $330{ }^{\circ} \mathrm{C}$ and were higher than the temperature measured in the rosettes (33 to $183{ }^{\circ} \mathrm{C}$; Table 2$)$. The relative water content $( \pm \mathrm{SE})$ was $190 \pm 18 \%$ in late dry season fire of 2009 and $104 \pm 17 \%$ in 2010 .

The residence time of temperatures above $60{ }^{\circ} \mathrm{C}$, considered lethal for plant tissues (Kayll 1968), was mostly below $3 \mathrm{~min}$ at $1 \mathrm{~cm}$ in height $(115 \pm 21 \mathrm{~s}-$ mean $\pm \mathrm{SE})$. Lethal temperatures tended to persist longer than $3 \mathrm{~min}$ at $50 \mathrm{~cm}$ in height (mean: $212 \pm 64 \mathrm{~s}$ ). The temperature inside $S$. nitens rosettes exceeded $60{ }^{\circ} \mathrm{C}$ in only four out of 13 rosettes measured, mostly $(n=3)$ during the late fires (Table 2). Lethal temperatures persisted for more than a minute in three of these four rosettes (Table 2; Fig. 2).

\section{Discussion}

We found no differences in total fuel load between areas unburned for 2 years compared to areas unburned for 5 years. These results contradict local communities' impression that longer fire intervals would potentially increase biomass and, consequently, fire intensity in the wet grasslands. Our results are comparable to other studies in humid and sub-humid savanna areas reporting that fuel load recovers within 2 years after fire or less (e.g., Chidumayo 2003; Cianciaruso et al. 2010; Miranda et al. 2010).

The fire intensities estimated in our experimental fires in "Cerrado" wet grasslands were lower (mostly <50\%) than the fire intensities found in other tropical and sub-tropical

Table 1 Fire behavior and abiotic parameters of 13 experimental fires in five wet grasslands in Jalapão region, in the Brazilian "Cerrado", during the early (June) dry season of 2009 and dry seasons of 2009 and 2010

\begin{tabular}{|c|c|c|c|c|c|c|c|c|c|c|c|}
\hline Sites & $\begin{array}{l}\text { Fire } \\
\text { type }\end{array}$ & Date & $\begin{array}{l}\text { Years } \\
\text { since } \\
\text { last fire }\end{array}$ & $\begin{array}{l}\text { Fuel load } \\
\left(\mathrm{kg}\left(\mathrm{m}^{2}\right)^{-1}\right)\end{array}$ & $\begin{array}{l}\text { Fuel } \\
\text { consumption } \\
(\%)\end{array}$ & $\begin{array}{l}\text { Fire } \\
\text { spread } \\
\left(\mathrm{km} \mathrm{h}^{-1}\right)\end{array}$ & $\begin{array}{l}\text { Fire } \\
\text { intensity } \\
\left(\mathrm{kW} \mathrm{m}^{-1}\right)\end{array}$ & $\begin{array}{l}\text { Heat } \\
\text { released } \\
\left(\mathrm{J}\left(\mathrm{m}^{2}\right)^{-1}\right)\end{array}$ & $\begin{array}{l}\text { Air } \\
\text { temperature } \\
\left({ }^{\circ} \mathrm{C}\right)\end{array}$ & $\begin{array}{l}\text { Relative } \\
\text { humidity } \\
(\%)\end{array}$ & $\begin{array}{l}\text { Wind } \\
\text { speed } \\
\left(\mathrm{km} \mathrm{h}^{-1}\right)\end{array}$ \\
\hline 1 & Early & June 2009 & 2 & 0.779 & 80.27 & 0.132 & 355.2 & 12069.3 & 33.3 & 67.0 & 2.50 \\
\hline 2 & Early & June 2009 & 2 & 0.438 & 60.58 & 0.210 & 240.1 & 6795.2 & 31.0 & 75.3 & 0.79 \\
\hline 3 & Early & June 2009 & 2 & 1.327 & 78.30 & 0.150 & 671.0 & 20567.5 & 35.8 & 56.5 & 4.00 \\
\hline 4 & Early & June 2009 & 2 & 0.805 & 81.06 & 0.240 & 674.6 & 12482.7 & 32.1 & 67.7 & 2.33 \\
\hline 5 & Early & June 2009 & 2 & 0.890 & 72.90 & 0.105 & 293.2 & 13788.8 & 32.4 & 73.3 & 2.14 \\
\hline 2 & Late & Sept. 2009 & 2 & 1.040 & 93.98 & 0.214 & 901.8 & 16120.0 & 28.3 & 95.8 & 4.38 \\
\hline 3 & Late & Sept. 2009 & 2 & 0.858 & 89.65 & 0.250 & 827.9 & 13297.8 & 32.9 & 74.7 & 5.37 \\
\hline 4 & Late & Sept. 2009 & 2 & 0.654 & 69.40 & 0.375 & 733.2 & 9942.3 & 34.5 & 73.7 & 0.17 \\
\hline 5 & Late & Sept. 2009 & 2 & 0.830 & 93.93 & 0.167 & 559.4 & 12861.3 & 29.0 & 86.5 & 2.08 \\
\hline 1 & Late & Sept. 2010 & 5 & 0.811 & 97.70 & 0.187 & 636.6 & 12565.3 & 34.7 & 53.4 & 9.30 \\
\hline 2 & Late & Sept. 2010 & 5 & 0.515 & 82.32 & 0.593 & 1083.3 & 7989.7 & 35.1 & 54.5 & 9.44 \\
\hline 3 & Late & Sept. 2010 & 5 & 0.793 & 96.98 & 0.225 & 745.3 & 12295.4 & 35.2 & 56.2 & 6.60 \\
\hline 4 & Late & Sept. 2010 & 5 & 0.654 & 96.70 & 0.210 & 572.2 & 10143.6 & 39.3 & 46.1 & 7.39 \\
\hline
\end{tabular}


Table 2 Maximum temperatures and maximum residence time of temperatures above $60{ }^{\circ} \mathrm{C}$ registered in nine experimental early (June 2009) and late (September 2009) dry season fires in five wet grasslands in Jalapão region, in the Brazilian "Cerrado"

\begin{tabular}{|c|c|c|c|c|c|c|c|c|c|}
\hline \multirow[t]{2}{*}{ Sites } & \multirow[t]{2}{*}{ Fire type } & \multirow[t]{2}{*}{ Years since last fire } & \multicolumn{3}{|c|}{ Maximum temperatures during fires $\left({ }^{\circ} \mathrm{C}\right)$} & \multicolumn{3}{|c|}{$\begin{array}{l}\text { Residence time - of lethal temperatures } \\
\left(>60{ }^{\circ} \mathrm{C}(\mathrm{s})\right)\end{array}$} & \multirow[t]{2}{*}{$\begin{array}{l}\text { Fire intensity } \\
\left(\mathrm{kW} \mathrm{m}^{-1}\right)\end{array}$} \\
\hline & & & $50 \mathrm{~cm}$ & $1 \mathrm{~cm}$ & Syngonanthus nitens rosette & $50 \mathrm{~cm}$ & $1 \mathrm{~cm}$ & S. nitens rosette & \\
\hline 1 & Early fire & 2 & 186 & 294 & 144 & 108 & 140 & 83 & 355.2 \\
\hline 2 & Early fire & 2 & 150 & 110 & 34 & 64 & 114 & 0 & 240.1 \\
\hline 3 & Early fire & 2 & 416 & 185 & 43 & 148 & 122 & 0 & 671.0 \\
\hline 4 & Early fire & 2 & 222 & 227 & 51 & 158 & 115 & 0 & 674.6 \\
\hline 5 & Early fire & 2 & 442 & 57 & 51 & 233 & 0 & 0 & 293.2 \\
\hline 2 & Late fire & 2 & 363 & 331 & 183 & 191 & 237 & 120 & 901.8 \\
\hline 3 & Late fire & 2 & 405 & 189 & 47 & 709 & 96 & 0 & 827.9 \\
\hline 4 & Late fire & 2 & 226 & 237 & 97 & 145 & 150 & 103 & 733.2 \\
\hline 5 & Late fire & 2 & 229 & 153 & 70 & 152 & 63 & 21 & 559.4 \\
\hline
\end{tabular}

Thermocouples were placed at 50 and $1 \mathrm{~cm}$ above soil surface and inside Syngonanthus nitens adult plant rosettes

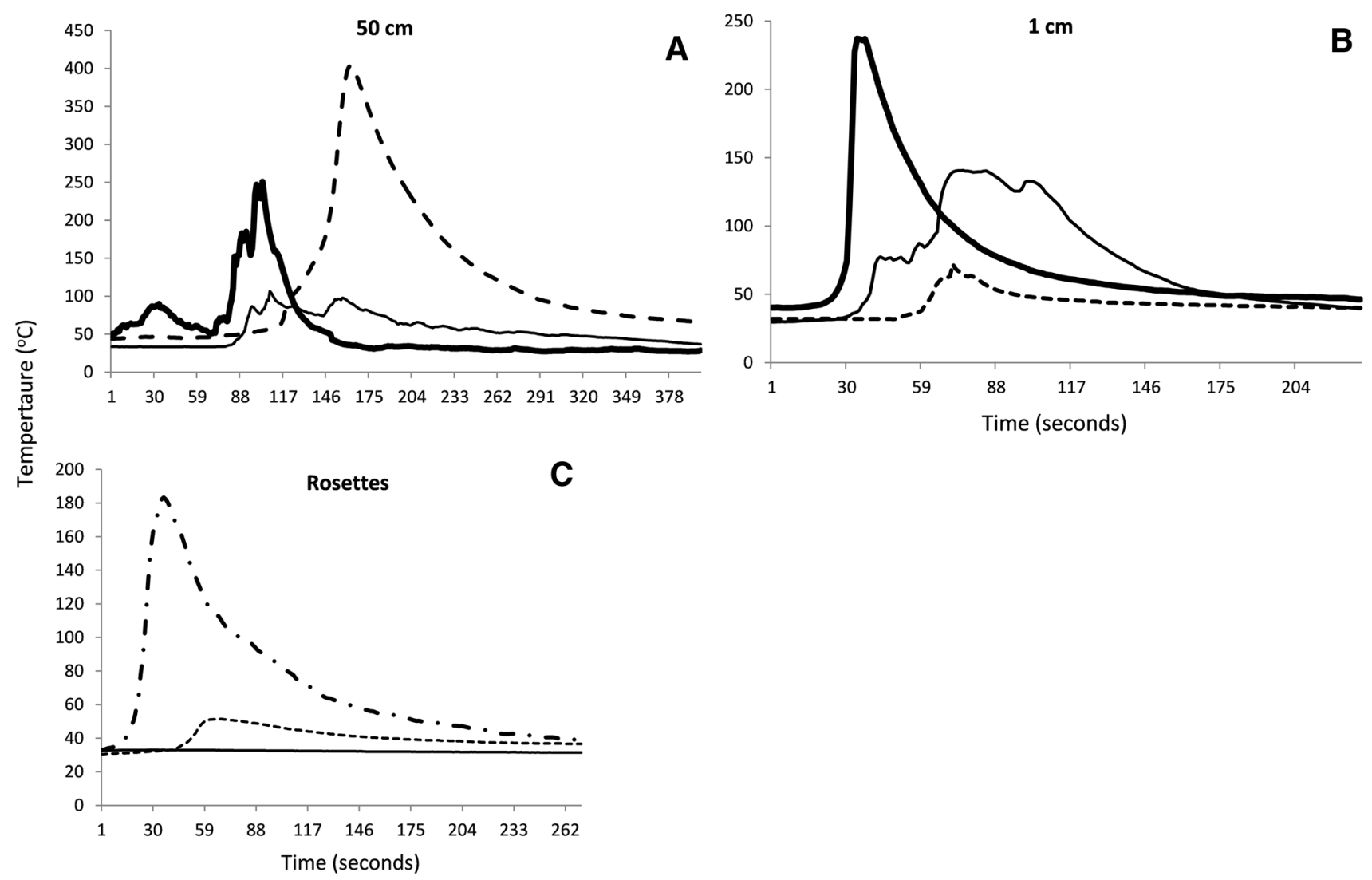

Fig. 2 Typical temperature curves during early and late dry season fires in wet grasslands in Jalapão, Brazil. In each panel, the bold continuous line represents the most common temperature profile curve during experimental fires; the other two curves per panel are other examples of observed profiles during nine experimental fires in five sites. a, thermocouples at $50 \mathrm{~cm}$ height, just above the herbaceous layer vegetation; b $1 \mathrm{~cm}$ height and $\mathbf{c}$ thermocouples placed inside Syngonanthus nitens rosettes

savannas physiognomies, where fuel load was similar (Table 3). This includes studies in "cerrado" dry grasslands ("campo sujo") and woodlands ("Cerrado" sensu stricto) reviewed by Miranda et al. (2009); grasslands and parklands in the Amazonian savannas in Northern Brazil (Barbosa and Fearnside 2005); woodlands in Zambia, South Africa (Shea et al. 1996; Govender et al. 2006); and Northern Australia (Williams et al. 1998). 
Table 3 Comparative table of fuel load and fire intensities found in this study and reported for other experimental fires in savanna environments

\begin{tabular}{|c|c|c|c|c|c|}
\hline \multirow[t]{2}{*}{ Study } & \multirow[t]{2}{*}{ Physiognomy } & \multirow[t]{2}{*}{ Region } & \multicolumn{2}{|c|}{ Intensity $\left(\mathrm{kW} \mathrm{m}^{-1}\right)$} & \multirow[t]{2}{*}{ Fuel load $\left(\mathrm{kg}\left(\mathrm{m}^{2}\right)^{-1}\right)$} \\
\hline & & & Minimum & Maximum & \\
\hline This study & Wet grasslands & Central Brazil & 240 & 1083 & $0.43-1.04$ \\
\hline Barbosa and Fearnside (2005) & Grassland & Roraima, Brazil & 1256 & 16,394 & $0.2-0.4$ \\
\hline Cardoso et al. (2000) & Wet grasslands & Pantanal, Brazil & - & - & $0.3-0.5$ \\
\hline Govender et al. $(2006)^{\mathrm{a}}$ & Woodland savanna & S. Africa & 638 & 2664 & $0.3-0.4$ \\
\hline Miranda et al. (2009) & Grasslands & Central Brazil & 1200 & 20,393 & $0.2-1.6$ \\
\hline Shea et al. (1996) & Woodland savanna & S. Africa, Zambia & 480 & 6130 & $2.2-5.5$ \\
\hline Williams et al. (1998) & Eucalypt savanna & N. Australia & 500 & 18,000 & $1.5-13$ \\
\hline
\end{tabular}

${ }^{a}$ Mean values obtained from 956 experimental fires, over 21 years

The lower fire intensity, we found compared to that in dry savannas physiognomies, can probably be attributed to the higher soil water availability year around in the wet grasslands, which allows for perennial plants to keep high moisture contents even during the dry season (Cardoso et al. 2000; Cianciaruso and Batalha 2008). Field measurements indicate that most $(71-81 \%)$ of the aboveground biomass in wet grasslands is still moist and alive even at the end of the dry season (Fidelis et al. 2013), in contrast to the dry aboveground biomass that characterize "Cerrado" dry grasslands and woodlands (Miranda et al. 2002, 2010).

Although we found no significant difference between early and late fires in the areas burned biennially, fire behavior and intensity varied across our five study sites. The two least intense fires-early fire in sites 2 and 5 (Table 1)-were associated with the lowest fuel combustion percentage. These two fires were carried out under the highest air relative humidity $(>73 \%)$ among all our early-season fires, and their low intensities might have been a consequence of higher fuel moisture as hypothesized by Baeza et al. (2002). With a low fuel load, the early fire in site 2 also had the lowest maximum temperatures among all 13 fires. On the other hand, the high fuel load in site 5 allowed for very high temperatures to occur especially at $50 \mathrm{~cm}$ height (Table 2).

Fire intensity was not affected by time since last fire. Fire intensities in the areas burned after 2 or 5 years since last fire were similar, mostly due to the fast recovery of the biomass of the herbaceous layer after fires (e.g., Chidumayo 2003; Cianciaruso et al. 2010; Miranda et al. 2010). Schmidt (2011) found that interannual rainfall variation has large effects on the population dynamics of one wet grassland species, S. nitens, with significantly higher mortality in low rainfall years. Also, low rainfall during the rainy season can cause soil water availability to decrease in wet grasslands during the following dry season, causing changes in the aboveground biomass (Toogood et al. 2008), which can drastically change fire behavior (Whelan 1995). However, that seems not to be the case during the study years; precipitation in $2009(1961 \mathrm{~mm})$ and 2010 (1895 mm) were high (ANA 2010). Therefore, the fast recovery of the herbaceous layer biomass associated with similar climatic condition (Table 1) resulted in similar fire rate of spread and fuel consumption resulting in similar fire intensities in the late dry season fires of 2009 and 2010.

Although fire intensity is an important measure of fire behavior, high temperature and residence time can be better predictors of fire impacts on the plant community, i.e., fire severity (Govender et al. 2006). The higher relevance of fire residence time compared to fire intensity seems to be even more important for predicting and understanding the effects of fire in grass and herbaceous species (Andersen et al. 2005). The residence times of high temperatures in our experimental fires were short and similar to those reported in other savanna physiognomies (Miranda et al. 1993; Savadogo et al. 2007).

Maximum air temperatures in our experimental fires were lower than the temperatures measured for other "Cerrado" fires (Miranda et al. 1993, 2009). These relatively low temperatures and a short residence time of high temperatures at $1 \mathrm{~cm}$ above the soil surface indicate that wet grassland fires are likely to have low impact on soil nutrients and water repellence. Chemical and physical processes that may cause water repellence start at about $170{ }^{\circ} \mathrm{C}$, organic matter and nitrogen volatilization occur at temperatures above $200{ }^{\circ} \mathrm{C}$, and the volatilization of nutrients such as potassium, phosphorous, and calcium only occur above $500{ }^{\circ} \mathrm{C}$ (reviewed by Certini 2005; Pivello et al. 2010). We rarely recorded temperatures above $170{ }^{\circ} \mathrm{C}$ close to the soil surface, and these lasted less than $30 \mathrm{~s}$. We therefore expect only short-term changes in soil properties due to fire in "Cerrado" wet grasslands, if at all (Certini 2005; Silva and Batalha 2008; Pivello et al. 2010). Soil structure and nutrient analyses from control 
(unburned) and late burned areas in all our study sites revealed no differences in soil properties that could be attributed to burning, nine months after the late fires of 2009 (Schmidt 2011).

Our results indicate that temperatures inside $S$. nitens rosettes might frequently remain below levels considered lethal $\left(60^{\circ} \mathrm{C}\right)$ during fires in the wet grasslands. The plant architecture, with leaves superimposed in a rosette format and high water content may insulate and protect plant essential tissues (Gill and Ingwersen 1976; Whelan 1995). Although our results might suggest that late dry season fires have a more severe effect on $S$. nitens compared to early fires (temperatures above $60{ }^{\circ} \mathrm{C}$ inside $S$. nitens rosettes-Table 2), this can also be a result of the reduced sample size (temperature measured inside 13 rosettes, with only four of them exceeding $60{ }^{\circ} \mathrm{C}$ ). We did not assess the survival of the 13 rosettes within which we placed the thermocouples during the experimental fires. Schmidt (2011) considering a much larger sample, found very similar survival rates among $S$. nitens adult individuals subject to late and early burns, as well as in control populations (94\% survival, $n=735 ; 92 \%, n=730$ and $93 \%, n=592$, respectively) in the same five wet grasslands sites.

To our knowledge, these are the first data on fire intensity and fire behavior on "Cerrado" wet grasslands. Although wet grasslands represent a small portion of the Brazilian "Cerrado" and other tropical savannas, these areas are ecologically very important in terms of water cycling and biodiversity. In addition, wet grasslands are commonly managed with fire for productive reasons by local communities (Dixon 2003), as well as for conservation purposes for managers. Therefore, better understanding fire behavior in such areas may help to better understand the fire effects on these environments, as well as inform management decisions on the needed fire management in tropical savannas, especially in the "Cerrado", where fire management is much needed (Durigan and Ratter 2016).

Our results showed that fires in wet grasslands tend to be less intense than in most dry savanna vegetation types, and that fire intensity and behavior remain similar after 2 or 5 years since last fire. Additionally, fires in early or late dry season have similar fire intensity and behavior; however, since late dry season fires tend to be more intense and would turn much harder to control if they were to scape to riparian or dry vegetation adjacent to wet grasslands, we suggest that early dry season fires are preferable to use for fire management purposes. This information is directly useful for the planning and implementation of fire management. This is especially important, since fire management in wet grasslands is key to prevent wildfires to reach fire-sensitive vegetation such as swampy forest and other riparian forests in "Cerrado".

Acknowledgments We thank Jalapão State Park for the research permit and all logistic support; Capes/Fulbright, Ibama, Instituto Sociedade População e Natureza (ISPN), the International Foundation for Science (IFS) and the University of Hawai'i for Grants; Jalapão local communities for participating in field activities and for allowing the experiments to be carried out in their lands. A.F. received financial support from FAPESP (2008/10049-9) and she has a productivity Grant from CNPq (306170/2015-9).

\section{References}

ANA-Agência Nacional de Águas (2010) Hidroweb. http://hidroweb. ana.gov.br/ Accessed Aug 2010

Andersen AN, Braithwaite RW, Cook GD, Corbett LK, Williams RJ, Douglas MM, Gill AM, Setterfield SA, Muller WJ (1998) Fire research for conservation management in tropical savannas: introducing the Kapalga fire experiment. Aust J Ecol 23:95-110

Andersen AN, Cook GD, Corbett LK, Douglas MM, Eager RW, Russell-Smith J, Setterfield SA, Williams RJ, Woinarski JCZ (2005) Fire frequency and biodiversity conservation in Australian tropical savannas: implications from the Kapalga fire experiment. Austral Ecol 30:155-167

Baeza MJ, Luis MD, Raventos J, Escarre A (2002) Factors influencing fire behaviour in shrublands of different stand ages and the implications for using prescribed burning to reduce wildfire risk. J Environ Manag 65:199-208

Barbosa RI, Fearnside PM (2005) Above-ground biomass and the fate of carbon after burning in the savannas of Roraima, Brazilian Amazonia. For Ecol Manag 216:295-316

Barbosa AS, Schmitz PI (1998) Ocupação indígena do Cerrado: esboço de uma história. In: Sano SM, Almeida SPd (eds) Cerrado ambiente e flora. Embrapa, Planaltina, pp 3-42

Bond WJ, Keeley JE (2005) Fire as a global 'herbivore': the ecology and evolution of flammable ecosystems. Trends Ecol Evol 20:387-394

Bond WJ, Woodward FI, Midgley GF (2005) The global distribution of ecosystems in a world without fire. New Phytol 165:525-538

Byram GM (1959) Combustion of forest fuels. In: McGraw KPD (ed) Forest fire: control and use. Hill Book Co, New York, pp 61-89

Cardoso EL, Crispim MA, Rodrigues CA, Baroni Jr W (2000) Biomassa aérea e produção primária do estrato herbáceo em campo de Elionurus muticus submetido a queima anual no Pantanal. Pesqui Agropecu Bras 35:1501-1507

Certini G (2005) Effects of fire on properties of forest soils: a review. Oecologia 143:1-10

Chidumayo EN (2003) Effect of tillage, clipping and climate on grass phytomass in a Zambian savanna. J Trop Ecol 19:407-415

Cianciaruso MV, Batalha MA (2008) A year in a Cerrado wet grassland: a non-seasonal island in a seasonal savanna environment. Braz J Biol 68:495-501

Cianciaruso MV, Silva IA, Batalha MA (2010) Above ground biomass of functional groups in the ground layer of savannas under different fire frequencies. Aust J Bot 58:169-174

Dayamba SD, Savadogo P, Zida D, Sawadogo L, Tiveau D, Oden PC (2010) Fire temperature and residence time during dry season burning in a Sudanian savanna-woodland of West Africa with implication for seed germination. J For Res 21:445-450

Development Core Team R (2016) R: a language and environment for statistical computing. R Foundation for Statistical Computing, Vienna 
Dixon AB (2003) Indigenous management of wetlands- experiences in Ethiopia. Ashgate, Hampshire

Durigan G, Ratter JA (2016) The need for a consistent fire policy for Cerrado conservation. J Appl Ecol 53:11-15

Falleiro RM (2011) Resgate do Manejo Tradicional do Cerrado com Fogo para Proteção das Terras Indígenas do Oeste do Mato Grosso: um Estudo de Caso. Biodiversidade Brasileira 1:86-96

Fidelis A, Lyra MFdS, Pivello VR (2013) Above- and below-ground biomass and carbon dynamics in Brazilian Cerrado wet grasslands. J Veg Sci 24:356-364

França H (2010) Os incêndios de 2010 nos parques nacionais do cerrado. Technical report.http://www.ufabc.edu.br/index.php?op tion=com_content $\&$ view=article $\&$ id=4109:professo-ra-da-ufabcmapeia-queimadas-em-unidades-de-conservacao-docerrado\&ca tid=587:2010\&Itemid=183. Accessed 15 Jun 2016

Furley P (2004) Tropical Savannas. Prog Phys Geog 28:581-591

Furley P, Rees RM, Ryan CM, Saiz G (2008) Savanna burning and the assessment of long-term fire experiments with particular reference to Zimbabwe. Prog Phys Geog 32:611-634

Gill AM, Ingwersen F (1976) Growth of Xanthorrhoea australis R.Br. in relation to fire. J Appl Ecol 13:195-206

Govender N, Trollope SW, Van Wilgen BW (2006) The effect of fire season, fire frequency, rainfall and management on fire intensity in savanna vegetation in South Africa. J Appl Ecol 43:748-758

Griffin GF, Friedel MH (1984) Effects of fire in central Australia rangelands. I-Fire and fuel characteristics and change in herbage and nutrients. Austral J Ecol 9:381-393

Kayll AJ (1968) Heat tolerance of tree seedlings. In: Proceedings of the tall timbers fire ecology conference. Tall Timbers Research Station, Tallahassee, pp 89-105

Lobo C (2014) Parque Nacional Implementa Manejo de Fogo. ICMBio/MMA. http://www.icmbio.gov.br/portal/ultimas-noti cias/4-destaques/4916-parque-nacional-implementa-projeto-demanejo-do-fogo. Accessed 15 Jun 2016

McGregor S, Lawson V, Christophersen P, Kennet R, Boyden J, Bayliss P, Liedloff A, McKaige B, Andersen AN (2010) Indigenous wetland burning: conserving natural and cultural resources in Australia's world heritage-listed Kakadu National Park. Hum Ecol 38:721-729

Miranda AC, Miranda HS, Dias IdFO, Dias BFdS (1993) Soil and air temperatures during prescribed Cerrado fires in Central Brazil. J Appl Ecol 9:313-320

Miranda HS, Bustamante MMC, Miranda AC (2002) The fire factor. In: Oliveira PS, Marquis RJ (eds) The Cerrados of Brazilecology and natural history of a neotropical savanna. Columbia University Press, New York, pp 51-68

Miranda HS, Sato MN, Nascimento Neto W, Aires FS (2009) Fires in the Cerrado, the Brazilian savanna. In: Cochrane MA (ed) Tropical fire ecology. Praxis, Chichester, pp 427-450

Miranda HS, Nascimento Neto W, Neves BMC (2010) Caracterização das queimadas de Cerrado. In: Miranda HS (ed) Efeitos do regime do fogo sobre a estrutura de comunidades de Cerrado: resultados do Projeto Fogo. Ibama, Brasília, pp 23-24

Mistry J (1998) Fire in the Cerrado (savannas) of Brazil: an ecological review. Prog Phys Geog 22:425-448

Myers RL (2006) Living with fire-sustaining ecosystems and livelihoods through integrated fire management. The Nature Conservancy, Tallahassee

Pereira Junior AC, Oliveira SLJ, Pereira JMC, Turkman MAA (2014) Modelling fire frequency in a Cerrado savanna protected area. PLoS One 9:e102380. doi:10.1371/journal.pone.0102380

Pivello VR (2011) The use of fire in the Cerrado and Amazonian rainforests of Brasil: past and present. Fire Ecol 7:24-39
Pivello VR, Oliveras I, Miranda HS, Haridasan M, Sato MN, Meirelles ST (2010) Effect of fires on soil nutrient availability in an open savanna in Central Brazil. Plant Soil 337:11-123

Ramos Neto MB, Pivello VR (2000) Lightning fires in a Brazilian savanna national park: rethinking management strategies. Environ Manag 26:675-684

Ratter JA, Ribeiro JF, Bridgewater S (1997) The Brazilian Cerrado vegetation and threats to its biodiversity. Ann Bot 80:223-230

Savadogo P, Zida D, Sawadogo L, Tiveau D, Tigabu M, Odén PC (2007) Fuel and fire characteristics in savanna-woodland of West Africa in relation to grazing and dominant grass type. Int $\mathbf{J}$ Wildland Fire 16:531-539

Schmidt IB (2011) Effects of local ecological knowledge, harvest and fire on golden-grass (Syngonanthus nitens, Eriocaulaceae), a non-timber forest product (NTFP) species from the Brazilian savanna. Dissertation, Botany Department/Ecology, Evolution and Conservation Biology program, University of Hawai'i at Manoa, Honolulu

Schmidt IB, Ticktin T (2012) When predictions from matrix population models and local ecological knowledge coincideEffects of flower stalk harvest on populations of an economically important non-timber forest product (NTFP) in the Brazilian savanna. Biol Conserv 152:187-195

Schmidt IB, Figueiredo IB, Scariot AO (2007) Ethnobotany and effects of harvesting on the population ecology of Syngonanthus nitens (Bong.) Ruhland (Eriocaulaceae), a NTFP from Jalapão region Central Brazil. Econ Bot 61:73-85

Shea RW, Shea BW, Kauffman JB (1996) Fuel biomass and combustion factors associated with fires in savanna ecosystems of South Africa and Zambia. J Geophys Res 101:23551-23568

Silva DM, Batalha MA (2008) Soil-vegetation relationships in cerrados under different fire frequencies. Plant Soil 331:87-96

Silva JMC, Bates JM (2002) Biogeographic patterns and conservation in the South American Cerrado: a tropical savanna hotspot. Bioscience 52:225-234

Simon MF, Grether R, Queiroz LPC, Skema R, Pennington T, Hughes CE (2009) Recent assembly of the Cerrado, a neotropical plant diversity hotspot, by in situ evolution of adaptations to fire. PNAS 106:20359-20364

Toogood SE, Joyce CB, Waite S (2008) Response of floodplain grassland plant communities to altered water regimes. Plant Ecol 197:285-298

Trollope LA, Trollope WSW (2002) Fire behaviour a key factor in the fire ecology of African grasslands and savannas. In: Viegas DX (ed) Forest fire research \& wildland fire safety. Millpress, Rotterdam, pp 18-23

VanWilgen BW, Govender N, Biggs HC (2007) The contribution of fire research to fire management: a critical review of a long-term experiment in the Kruger National Park, South Africa. Int J Wildland Fire 16:519-530

Whelan RJ (1995) The ecology of fire. Cambridge University Press, Cambridge

Williams RJ, Gill AM, Moore PHR (1998) Seasonal changes in fire behavior in a tropical savanna in Northern Australia. Int $\mathbf{J}$ Wildland Fire 8:227-239

Yibarbuk D, Whitehead PJ, Russell-Smith J, Jackson D, Godjuwa C, Fisher A, Cooke P, Choquenot D, Bowman DMJS (2001) Fire ecology and aboriginal land management in Central Arnhem Land, Northern Australia: a tradition of ecosystem management. J Biogeogr 28:325-343

Zimmermann J, Higgins SI, Grimm V, Hoffmann J, Linstadter A (2010) Grass mortality in semi-arid savanna: the role of fire, competition and self-shading. Perspect Plant Ecol 12:1-8 